\title{
Effect of Phytobiotic and Exogenous Enzyme Supplementation on Economic Efficiency and Cost of Production of Broiler Chickens
}

\author{
P. Singh ${ }^{1 *}$, V.K. Singh ${ }^{1}$, D. Tiwari ${ }^{1}$, S. Gautam ${ }^{1}$, V.B. Singh ${ }^{1}$ and Vipin ${ }^{2}$ \\ ${ }^{1}$ Department of Animal Nutrition, College of Veterinary Science and \\ Animal Husbandry, Narendra Deva University of Agriculture and Technology, \\ Kumarganj-224 229, Ayodhya (U.P.), India \\ ${ }^{2}$ Center of Advanced Studies in Animal Nutrition, ICAR-Indian Veterinary Research Institute, \\ Izatnagar, (U.P) 243122, India, India \\ *Corresponding author
}

\begin{tabular}{|l|}
\hline Ke y w o r d s \\
Phytobiotics, \\
$\begin{array}{l}\text { Enzyme, Economic } \\
\text { efficiency, Broiler } \\
\text { chicks }\end{array}$ \\
\hline Article Info \\
\hline $\begin{array}{l}\text { Accepted: } \\
\text { 15 April } 2020 \\
\text { Available Online: } \\
10 \text { May } 2020\end{array}$ \\
\hline
\end{tabular}

\section{A B S T R A C T}

The aim of this work was to compare the efficacy of a phytogenic feed additive (PFA) and exogenous enzyme supplementation on the economic efficiency and cost of production of broiler chickens. Day-old chicks of Cobb $400 \mathrm{Y}(\mathrm{n}=300)$ were distributed randomly into six groups of 50 chicks each, which were further subdivided into five replicates of ten chicks each. These six groups fed a basal diet without any supplement (NCON), or that supplemented with an antibiotic (PCON), herbal powder mixture (PHY), enzyme mixture (ENZ), the combination of $1 \%$ herbal mixture with the enzyme $\left(\mathrm{PHE}_{1}\right)$ and combination of $2 \%$ herbal mixture with the enzyme ( $\left.\mathrm{PHE}_{2}\right)$ respectively. The effect of these supplements on economic efficiency and cost of production was assessed in a sixweek study. Feed productivity was significantly $(\mathrm{P}<0.05)$ higher in $\mathrm{PHE}_{1}, \mathrm{PHE}_{2}, \mathrm{PCON}, \mathrm{PHY}$ and ENZ than NCON group. Cost productivity of PCON and $1 \%$ herbal mixture with enzyme ( $\left.\mathrm{PHE}_{1}\right)$ group was significantly $(\mathrm{P}<0.05)$ higher than the NCON group. Benefit: cost ratio, profit index and return on investment were following the same trend, where $\mathrm{PHE}_{1}$ group was significantly higher than the NCON group but almost similar to PCON group birds. The feed price ratio of $\mathrm{PHE}_{1}$ and $\mathrm{PHE}_{2}$ had significantly $(\mathrm{P}<0.05)$ higher value than NCON but similar to PCON group. The return on feed of $\mathrm{PHE}_{1}$ group was highest than all treated groups but similar to $\mathrm{PCON}$ and $\mathrm{PHE}_{2}$ group and significantly higher than NCON group. The break-even output percent of combination of $2 \%$ herbal mixture with enzyme $\left(\mathrm{PHE}_{2}\right)$ group was significantly higher than $\mathrm{NCON}$, and lowest was of the PCON group. Feed cost per kg body weight gain was significantly $(\mathrm{P}<0.05)$ higher in NCON followed by $\mathrm{PHE}_{2}, \mathrm{PHY}, \mathrm{ENZ}, \mathrm{PCON}$ and $\mathrm{PHE}_{1}$. Feed cost per kg body weight gain of $\mathrm{PHE}_{1}$ was similar to PCON group. Economic efficiency index percent was significantly higher in all treated groups than NCON group highest in $\mathrm{PHE}_{1}$ which was similar to PCON. Cost index (CI) percent of NCON group was significantly higher than all treated group. Profitability percent of PCON group was highest than all other groups but almost similar to $\mathrm{PHE}_{1}$ and $\mathrm{PHE}_{2}$ group and significantly $(\mathrm{P}<0.05)$ lower than NCON group. The Economic efficiency $(\mathrm{EE})$ of antibiotic, the combination of $1 \%$ herbal mixture with the enzyme ( $\left.\mathrm{PHE}_{1}\right)$ and combination of $2 \%$ herbal mixture with the enzyme $\left(\mathrm{PHE}_{2}\right)$ fed group was significantly higher than NCON and PHY group. So, it can be concluded that a combination of $1 \%$ herbal mixture with enzyme $\left(\mathrm{PHE}_{1}\right)$ feed additives in broilers feed can be an effective alternative of antibiotic growth promoters. 


\section{Introduction}

The poultry industry is one of the most popular livestock enterprises adopted by small and medium-scale farmers as it offers the highest turnover rate and quicker returns on investment outlay. The benefit of broiler production is eroded by the high cost of feed and it has been well established that feed alone account for about $70 \%$ of the total cost of poultry production. To exploit the maximum profit from birds, maintaining sound gut health and its function is important. Antibiotics have revolutionized the intensive poultry to promote growth, production and feed conversion efficiency by improving gut health and reduction of sub-clinical infections. However, the use of antibiotic growth promoter (AGP) can result in the development of drug-resistant bacteria. These resistant bacteria increase the effective dose rate of antibiotics some time make theme ineffective and thus it is public health concern (Torres et al., 2010). This has led to the many countries to ban most of the antibiotic as AGP in animal production. It is known that the essential oils present in the phytogenic feed additives (PFA) promote gut functions by stimulating the secretion of digestive enzymes, bile and mucus (Platel and Srinivasan, 2004), the terpenoids and phenolic compounds help the animals to combat with the oxidative stress of the animals come across (Aeschbach et al., 1994) and compounds like carvacrol, other terpenoids and aldehydes present in most of the PFA exert substantial antimicrobial effects (Mathlouthi et al., 2012) thus establishing eubiosis in the gut. Phytobiotics are plantderived natural bioactive compounds that can be added to the feed to improve the performance and well-being of animals (Windisch et al., 2008). Phytobiotics represent a wide range of bioactive compounds that can be extracted from various plant sources, such as herbs and spices.
Antimicrobial activity and immune enhancement are the two major properties belonging to phytobiotics which are essential for the health and well-being of the chicken (Yang et al., 2009; Fallah et al., 2013). Poultry naturally produces enzymes to aid the digestion of feed nutrients. However, they do not have an enzyme to break down fibre completely and need exogenous enzymes in feed to aid digestion. A corn-based meal diet, which supplies the majority of the energy for broilers, is recommended worldwide as the most common broiler feed. Although it is highly digestible, the possibility of improving its utilization may still exist because the diet contains non-starch polysaccharides (NSP) and it acts as a substrate for microfloral growth through fermentation. This may lead to reduced digestion and dietary utilization efficiency, as these compounds increase the water holding capacity and viscosity of the digesta. An enzyme presence within the diet appears to have a dual action on the intestinal microflora within poultry. Enzymes may reduce the presence of bacterial pathogens in the ileum and therefore increase the digestibility of starch and protein for the bird, and also increase the fermentable proportions of small sugar substrates from arabinoxylans and $\beta$-glucans by the caecal microflora (Bedford, 2000). Enzymes have also decreased intestinal viscosity in broilers (Marron et al., 2001). Enzymes can reverse the effects of anti-nutrients such as lectins and trypsin inhibitors (Bedford, 1996). The enzyme may also liberate components from the cell wall that can be used nutritionally, which would otherwise be unavailable to the bird for digestion (Bedford Introduction 3 and Schulze, 1998). Addition of multi-enzyme preparations that included hemicellulase to poultry feed, showed an overall improvement in poultry performance (Malathi and Devegowda, 2001). This improvement may be due to increased crude protein and energy digestibility (Kocher et al., 2002). Therefore 
to explore the optimizing potential of phytobiotics and/or exogenous enzymes in economic efficiency and cost of production, the present study was conducted in broiler chickens which could contribute to feeding strategies of the future.

\section{Materials and Methods}

A 300 day old Cobb 400Y strain chicks $(n=300)$ were purchased from a commercial hatchery and randomly distributed into 6 groups of 50 chicks in each group. Then each group was further subdivided into five replicates, which comprises 10 chicks in each subgroup. Feed and water were provided $a d$ $l i b$ entire the study period. Each groups were kept hygienically on the floor litter system in separate flocks. All the birds were reared adopting uniform management conditions. The floor was thoroughly cleaned, disinfected and dried before spreading the dry rice husk as bedding material. The rice husk was evenly spread to get about $5-7 \mathrm{~cm}$ thickness. The racking of litter was done at regular interval to prevent any cake formation. The chicks were brooded at $35{ }^{0} \mathrm{C}$ during the first week and thereafter the temperature was reduced by $3^{0} \mathrm{C}$ every week until the temperature reached room temperature i.e. $25 \pm 1^{0} \mathrm{C}$. The birds were vaccinated against the prevailing disease. The chicks were placed on one of the five dietary treatments i.e. either a basal diet without any supplement (NCON) or that supplemented with an antibiotic (PCON), herbal powder mixture (PHY), enzyme mixture (ENZ), the combination of $1 \%$ herbal mixture with the enzyme $\left(\mathrm{PHE}_{1}\right)$ and combination of $2 \%$ herbal mixture with the enzyme $\left(\mathrm{PHE}_{2}\right)$. The Herbal Powder mixture contains the Turmeric rhizome, Punarnava root, Ashwagandha root, Bhuiamla root, Neem leaf, Tulsi leaf, Aloe Vera leaf, Mangrail seed, Methi Seed and Garlic bulb and enzyme mixture contain Xylanase, Beta-Glucanase, Cellulase, Protease and Amyloglucosidase. The feeding of birds was divided into three different phases those are pre-starter (1-7 days), starter phase (8-21 days) and finisher days (22-42 days) separately according to BIS (2007) and the ingredients of feed are given in table 1 and 2. Body weights of chicks were recorded on the weekly interval from day 0 to day 42 , also recorded the replicate-wise total feed consumed to calculate the commercial viability of this phytogenic and enzyme product in terms of economic efficiency and cost of production.

\section{Statistical analysis}

Data were subjected to statistical analysis under completely randomized design employing the one-way analysis of variance (Snedecor and Cochran, 1989). The means of different treatments were compared with Duncan multiple range tests (Duncan, 1955).

\section{Results and Discussion}

The chemical composition of basal diets are presented in Table 1, chemical composition of Pre-starter, starter and finisher ration is presented in Table 2, the information on comparative cost of productivity under different dietary treatment groups are presented in Table 3 and the information on Economic efficiency of broilers under different dietary treatment groups are presented in Table 4. The results showed equal chick cost as well as the miscellaneous items for each bird distributed under different dietary treatments. The total feed cost was significantly $(\mathrm{P}<0.05$, Table 3$)$ higher in $\mathrm{PHE}_{1}$ than ENZ group birds, in other groups total cost, are almost similar $(\mathrm{P}>0.05)$. The feed additive cost was significantly $(\mathrm{P}<0.05$, Table 3) higher in $\mathrm{PHE}_{2}$ group birds followed by $\mathrm{PHE}_{1}, \mathrm{PHY}, \mathrm{PCON}, \mathrm{ENZ}$ and $\mathrm{NCON}$ group birds. The feed additive cost of $\mathrm{PHE}_{2}$ and $\mathrm{PHE}_{1}$ was highest because both herbs and enzymes were added. The feed productivity of 
$\mathrm{PHE}_{1}$ group was significantly $(\mathrm{P}<0.05$, Table 3) higher than NCON and similar to PCON group birds. Among the treatment group feed productivity of PHY and ENZ group was lowest which was almost similar $(\mathrm{P}>0.05)$ to NCON group. The cost productivity of the PCON group was higher than any other group birds but almost similar $(\mathrm{P}>0.05)$ to $\mathrm{PHE}_{1}$ and significantly $(\mathrm{P}<0.05$, Table 3$)$ higher than NCON group birds. Cost productivity of only Phytobiotics fed group was the same $(\mathrm{P}>0.05)$ to the NCON group. The feed price ratio of $\mathrm{PHE}_{1}$ (1.784) group was significantly $(\mathrm{P}<0.05$, Table 3) higher than NCON (1.520) group.

On observing the data it was found that benefit: cost ratio of $\mathrm{PHE}_{1}$ and $\mathrm{PCON}$ group was significantly $(\mathrm{P}<0.05$, Table 4$)$ higher than NCON group birds and lowest one found in the PHY group which was almost similar $(\mathrm{P}>0.05)$ to NCON group. A similar trend was found in the profit index and return on investment where the higher value was found in the PCON group followed by $\mathrm{PHE}_{1}, \mathrm{ENZ}$, $\mathrm{PHE}_{2}, \mathrm{NCON}$ and lowest in the PHY group. Return on feed was significantly $(\mathrm{P}<0.05$, Table 4) higher in $\mathrm{PHE}_{1}$ (49.42), $\mathrm{PHE}_{2}$ (47.02) and PCON (47.76) group birds in comparison to NCON (42.17) group. The break-even output (\%) was significantly $\left(\mathrm{P}<0.05\right.$, Table 4) higher in $\mathrm{PHE}_{2}(89.40)$ group followed by PHY (87.20), NCON (86.80), ENZ (85.20), PHE $_{1}$ (84.00) and PCON (80.80) group birds. Feed cost per kg BWG was significantly $(\mathrm{P}<0.05$, Table 4) higher in NCON (57.52) group than all other treated groups and lowest was found in the $\mathrm{PHE}_{1}$ group. Economic efficiency index was significantly $(\mathrm{P}<0.05$, Table 4$)$ higher in the $\mathrm{PHE}_{1}$ similar to the PCON group whereas the lowest was found in the NCON group in all groups. Cost index percent was significantly $(\mathrm{P}<0.05$, Table 4$)$ higher in the NCON group birds than all treated groups. Profitability percent was significantly $(\mathrm{P}<0.05$, Table 4) higher in the PCON group than any other group and the lowest value was found in the NCON group and all other groups were almost similar. The economic efficiency was also significantly $(\mathrm{P}<0.05$, Table 4$)$ higher in the PCON group than any other group.

The high profit in $\mathrm{PHE}_{1}$ group of the present study is in line with the findings of Singh et al., (2016) who reported that dietary inclusion of phytobiotics in the rations was more beneficial in broiler production. Saini et al., (2015) found that combination of Ashwagandha and Enzyme improved the performance of broiler birds. Similar results have been reported by Ihsan (2003), where the broilers fed rations with added kalongi fetched more profit as compared to using rations without supplementation of this herbal growth promoter. Mehala and Moorthy (2008) reported that the inclusion of Curcuma longa at 0.1 percent in broiler feed improved return over feed cost per kilogram live weight of broiler at the $6^{\text {th }}$ week of age. Similarly, Namagirilakshmi (2005) observed the cost of feed to produce one $\mathrm{kg}$ live broiler chicken was lowest in $0.50 \%$ turmeric supplemented groups. Mahmood et al., (2014) reported that supplementation of various commercial herbal growth promoters in the ration exhibited an increase in the profit margin of broilers as compared to those using ration without supplementation. Karangiya et al., (2016) found that supplementation of ginger in the diet of birds was found to be more economical than other groups. The result of higher performance of $\mathrm{PHE}_{1}$ group than $\mathrm{PHE}_{2}$ group was favoured by Fasuyi and Oloyede (2017) where he found lower concentration of garlic treatment give better results than higher concentration. 
Table.1 Ingredient and composition of basal diets (kg per quintal)

\begin{tabular}{|c|c|c|c|}
\hline Ingredient & Pre-starter & Starter & Finisher \\
\hline Maize & 50.42 & 55.52 & 59.82 \\
\hline Soybean meal & 42.00 & 36.40 & 27.40 \\
\hline Rice polish & - & - & 5.00 \\
\hline Vegetable fat & 4.48 & 5.18 & 0.40 \\
\hline Dicalcium phosphate & 1.15 & 0.97 & 0.75 \\
\hline Limestone powder & 0.90 & 1.04 & 0.36 \\
\hline Common salt & 0.40 & 0.38 & 0.16 \\
\hline DL-Methionine & 0.25 & 0.18 & 0.03 \\
\hline Lysine & 0.15 & 0.08 & 0.10 \\
\hline Choline chloride & 0.10 & 0.10 & 0.05 \\
\hline Vitamin premix & 0.05 & 0.05 & 0.10 \\
\hline Mineral premix & 0.10 & 0.10 & \\
\hline
\end{tabular}

*Supplies per kg diet: Vitamin A, 16,500IU; Vitamin D3, 3200IU; Vitamin E, 12mg; Vitamin K, 2 mg; Vitamin B2,

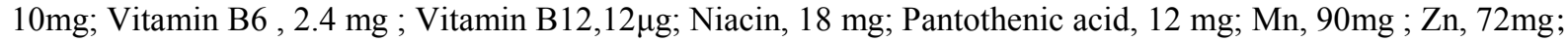
$\mathrm{Fe}, 60 \mathrm{mg} ; \mathrm{Cu}, 10 \mathrm{mg} ; \mathrm{I}, 1.2$

Table.2 Nutrient composition of pre-starter, starter and finisher ration

\begin{tabular}{|c|c|c|c|}
\hline \multirow{2}{*}{ Nutrients } & \multicolumn{3}{|c|}{ Composition } \\
\cline { 2 - 4 } & Pre-starter & Starter & Finisher \\
\hline Dry Matter (\%) & 87.15 & 87.77 & 89.22 \\
\hline Crude protein (\%) & 23.14 & 22.09 & 20.31 \\
\hline Crude fiber (\%) & 3.05 & 3.25 & 3.45 \\
\hline Ether extract (\%) & 4.98 & 5.80 & 7.78 \\
\hline Total ash (\%) & 5.79 & 5.18 & 6.86 \\
\hline Metabolizable energy * $^{*}$ Kcal/kg) & 3003.10 & 3107.00 & 3203.40 \\
\hline
\end{tabular}

*Calculated value 
Table.3 Comparative cost of productivity under different dietary treatment groups

\begin{tabular}{|c|c|c|c|c|c|c|c|c|}
\hline Attributes & NCON & PCON & PHY & ENZ & PHE $_{1}$ & $\mathrm{PHE}_{2}$ & SEM & $\begin{array}{c}\mathbf{P} \\
\text { value }\end{array}$ \\
\hline Chick cost & 42.00 & 42.00 & 42.00 & 42.00 & 42.00 & 42.00 & 0.00 & - \\
\hline \multicolumn{9}{|c|}{ Feed cost $(\mathbf{k g})$} \\
\hline Pre-starter & 4.49 & 4.24 & 4.26 & 4.42 & 4.42 & 4.45 & 0.035 & 0.196 \\
\hline Starter & $30.25^{\mathrm{b}}$ & $28.04^{\mathrm{d}}$ & $29.20^{c}$ & $28.97^{\mathrm{c}}$ & $28.84^{c}$ & $30.79^{a}$ & 0.182 & $<0.001$ \\
\hline Finisher & $73.28^{\mathrm{cd}}$ & $77.79^{\mathrm{ab}}$ & $75.33^{\mathrm{bc}}$ & $72.18^{d}$ & $78.77^{\mathrm{a}}$ & $74.61^{\mathrm{cd}}$ & 0.563 & $<0.001$ \\
\hline Total & $108.03^{\mathrm{bc}}$ & $110.08^{\mathrm{ab}}$ & $108.80^{\mathrm{abc}}$ & $105.58^{\mathrm{c}}$ & $112.04^{\mathrm{a}}$ & $109.87^{\mathrm{ab}}$ & 0.548 & 0.009 \\
\hline $\begin{array}{l}\text { Herbal/enzyme/antibiotic } \\
\text { cost }(\mathrm{Rs} / \text { bird) }\end{array}$ & $00.00^{\mathrm{f}}$ & $2.59^{\mathrm{d}}$ & $11.78^{b}$ & $2.24^{\mathrm{e}}$ & $12.30^{\mathrm{b}}$ & $13.20^{\mathrm{a}}$ & 1.019 & $<0.001$ \\
\hline Miscellaneous & 5.00 & 5.00 & 5.00 & 5.00 & 5.00 & 5.00 & 0.000 & - \\
\hline Feed productivity & $0.452^{\mathrm{c}}$ & $0.512^{\mathrm{ab}}$ & $0.484^{\mathrm{bc}}$ & $0.484^{\mathrm{bc}}$ & $0.532^{\mathrm{a}}$ & $0.508^{\mathrm{ab}}$ & 0.006 & 0.001 \\
\hline Cost productivity & $0.011^{\mathrm{c}}$ & $0.013^{\mathrm{a}}$ & $0.011^{\mathrm{c}}$ & $0.012^{\mathrm{bc}}$ & $0.012^{\mathrm{ab}}$ & $0.012^{\mathrm{bc}}$ & 0.0001 & 0.003 \\
\hline Feed price ratio & $1.520^{c}$ & $1.728^{\mathrm{ab}}$ & $1.622^{\mathrm{bc}}$ & $1.622^{\mathrm{bc}}$ & $1.784^{\mathrm{a}}$ & $1.698^{\mathrm{ab}}$ & 0.020 & 0.001 \\
\hline
\end{tabular}

Values with different small letter superscripts in a row differ between groups significantly $(\mathrm{P}<0.05)$.

Table.4 Economic efficiency of broiler under different dietary treatment groups

\begin{tabular}{|c|c|c|c|c|c|c|c|c|}
\hline Attributes & NCON & PCON & PHY & ENZ & PHE $_{1}$ & $\mathrm{PHE}_{2}$ & SEM & P value \\
\hline $\begin{array}{l}\text { Benefit: Cost } \\
\text { ratio }\end{array}$ & $0.062^{c}$ & $0.19^{\mathrm{a}}$ & $0.054^{c}$ & $0.104^{b c}$ & $0.166^{\mathrm{ab}}$ & $0.096^{b c}$ & 0.013 & 0.003 \\
\hline Profit index & $0.054^{\mathrm{c}}$ & $0.156^{\mathrm{a}}$ & $0.052^{\mathrm{c}}$ & $0.092^{\mathrm{bc}}$ & $0.140^{\mathrm{ab}}$ & $0.086^{\mathrm{bc}}$ & 0.010 & 0.004 \\
\hline $\begin{array}{l}\text { Return on } \\
\text { investment }\end{array}$ & $6.06^{c}$ & $18.95^{\mathrm{a}}$ & $5.44^{c}$ & $10.41^{\mathrm{bc}}$ & $16.70^{\mathrm{ab}}$ & $9.61^{b c}$ & 1.310 & 0.003 \\
\hline Return on feed & $42.17^{\mathrm{c}}$ & $47.76^{\mathrm{ab}}$ & $44.97^{b c}$ & $44.87^{\mathrm{bc}}$ & $49.42^{\mathrm{a}}$ & $47.02^{\mathrm{ab}}$ & 0.579 & 0.001 \\
\hline $\begin{array}{l}\text { Break even } \\
\text { output }(\%)\end{array}$ & $86.80^{\mathrm{bc}}$ & $80.80^{\mathrm{e}}$ & $87.20^{b}$ & $85.20^{\mathrm{cd}}$ & $84.00^{\mathrm{d}}$ & $89.40^{\mathrm{a}}$ & 0.548 & $<0.001$ \\
\hline $\begin{array}{l}\text { Feed cost per } \\
\text { kg BWG }\end{array}$ & $57.52^{\mathrm{a}}$ & $52.83^{d}$ & $53.81^{\mathrm{c}}$ & $53.19^{\mathrm{b}}$ & $52.12^{\mathrm{d}}$ & $54.85^{\mathrm{b}}$ & 0.348 & $<0.001$ \\
\hline $\begin{array}{c}\text { Economic } \\
\text { efficiency index } \\
(\%)\end{array}$ & $83.62^{d}$ & $91.05^{\mathrm{a}}$ & $89.41^{b}$ & $87.18^{c}$ & $92.30^{\mathrm{a}}$ & $87.68^{c}$ & 0.561 & $<f f 0.001$ \\
\hline $\begin{array}{c}\text { Cost index } \\
\text { percent }\end{array}$ & $119.59^{\mathrm{a}}$ & $109.82^{\mathrm{d}}$ & $111.86^{\mathrm{c}}$ & $114.73^{b}$ & $108.36^{\mathrm{d}}$ & $114.04^{b}$ & 0.723 & $<0.001$ \\
\hline $\begin{array}{l}\text { Profitability } \\
\text { percent }\end{array}$ & $106.04^{c}$ & $118.95^{\mathrm{a}}$ & $105.44^{c}$ & $110.41^{b c}$ & $116.70^{\mathrm{ab}}$ & $109.61^{\mathrm{ab}}$ & 1.310 & 0.003 \\
\hline $\begin{array}{l}\text { Economic } \\
\text { efficiency }\end{array}$ & $0.062^{c}$ & $0.19^{\mathrm{a}}$ & $0.054^{\mathrm{c}}$ & $0.104^{b c}$ & $0.166^{\mathrm{ab}}$ & $0.096^{b c}$ & 0.013 & 0.003 \\
\hline
\end{tabular}

Values with different small letter superscripts in a row differ between groups significantly $(\mathrm{P}<0.05)$.

Fasuyi and Oloyede (2017) found that birds fed on $2 \mathrm{gm} / \mathrm{kg}$ garlic supplemented diets had the best net returns per bird than the negative control group and the higher concentration of garlic fed group. Similarly, Karangiya et al., (2016) found that alone garlic and ginger give 
better return over feed cost than the combination of both due to higher concentration. Gade et al., (2017) reported that the net profit per bird was highest in the treatment group supplemented with xylanase at the rate of $60 \mathrm{~g} /$ ton and $100 \mathrm{~g} / \mathrm{ton}$ of feed. Ahmed et al., (2015) found higher economic gain in terms of total return and net profit in enzymes supplemented broilers than the control group. Similarly, Onu et al., (2011) reported that the addition of enzyme to broiler's feed reduced the cost of feed intake. Increase in the profit margin of the broiler chickens fed rations containing one percent herbal feed additives and exogenous enzymes in the present study was might be attributed to the better efficiency of feed utilization due to reduction in viscosity of intestinal contents, healthier gut, improved digestibility of nutrients that resulted in more growth and better feed to gain ratio. Same findings are also reported by Haq et al., (2012) that net profit per bird was found to be Rs. 25.80 by xylanase enzyme supplementation. Javed et $a l$. , (2009) noticed significantly higher weight gain in Ashwagandha along with other herbs treated group. Karangiya et al., (2016) reported that return on feed cost was highest in garlic supplemented group as compared to control. Similarly, Oleforuh-Okoleh et al., (2014) recorded that highest revenue and net return when birds were fed with herbal supplemented diet but Puvaka et al., (2016) reported lowest feed cost for per kg body weight gain at herbal powder supplementation in the diet of broiler chickens. They also reported that supplementation of herbal powder in the diet leads to higher economic efficiency index as well as lower cost in broiler production. Similarly, Abd El- Latif et al., (2002) observed that the inclusion of herbal feed additives resulted in the least feed cost $/ \mathrm{kg}$ gain in Japanese quail. EL-Faham et al., (2014) also found better economical and relative efficiency values in chicks fed diet contained herbal substance as compared with the control group. In concurrence with our findings, Abaza et al., (2008) also reported better economic efficiency and relative economic efficiency in birds that supplemented with black seed oil. Similarly, Abo Omar et al., (2016) also found better economic efficiency in the birds fed a commercial herbal preparation compared to the control birds. In agreement with our findings, Moustafa (2006) and Issa and Abo Omar (2012) found improved the economic efficiency of broilers on supplementation of herbal extracts. Abd El- Latif et al., (2002) also reported that the inclusion of herbal feed additives in Japanese quail diet resulted in the higher percentage of economic efficiency compared with the control diet. This improvement could be due to improving the feed conversion or reducing the amount of feed required to produce one unit of meat.

Singh et al., (2018) also reported feed productivity, feed price ratio, feed cost per $\mathrm{kg}$ body weight gain, return on feed, gross return and break-even output values were significantly $(\mathrm{P}<0.05)$ higher in herbal supplemented groups as compare to control. They also reported cost productivity, Benefit: cost ratio and Return on investment of phytogenic treated birds similar to control group and feed price ratio and feed productivity, Feed cost per $\mathrm{kg}$ body weight gain, Cost index (CI) and Gross return of herbal treated groups were similar to antibiotics supplemented group. Cost productivity and Benefit: cost ratio of herbal treated groups was significantly $(\mathrm{P}<0.05)$ lower than antibiotics supplemented group birds.

In conclusions, data of the present study indicated that supplementation of phytobiotics and enzyme separately and in combination did not much profitable as compare to the antibiotic group but give better result than the control group and only fed phytobiotics 
group. The combination of $1 \%$ phytobiotics and enzyme can be used as an alternative to because of antibiotic growth promoters in poultry feed.

\section{References}

Abaza, I.M., Shehata, M.A., Shoieb, M.S. and Hassan, I.I. 2008. Evaluation of some natural feed additive in growing chick diets. International journal of poultry science, 7 (9): 872-879.

Abd El-Latif, Faten, S.A., Ahmed, A. and ElKaiaty, A.M. 2002. Effect of feeding dietary thyme, black cumin, dianthus and fennel on productive and some metabolic responses of growing Japanese quail. Egyptian Poultry Science Journal, 22(1): 109- 125.

Abo Omar, J., Hejazi, A. and Badran, R. 2016. Performance of broilers supplemented with natural herb extract. Open Journal of Animal Sciences, 5, 68-74.

Aeschbach, R., Loliger, J., Scott, B.C., Murcia, A., Butler, J., Halliwell, B. and Aruoma, O.I. 1994. Antioxidant actions of thymol, carvacrol, 6-gingerol, zingerone and hydroxytyrosol. Food Chemical Toxicology, 32: 31-36.

Ahmad, A., Husain, A. and Mujeeb, M. 2013. A review on therapeutic potential of Nigella sativa: a miracle herb. Asian Pacific Journal of Tropical Biomedicine, 3: 337-52.

Bedford, M. 2000. Removal of antibiotic growth promoters from poultry diets: implications and strategies to minimise subsequent problems. World's Poultry Science Journal, 56, pp. 347-365.

Bedford, M.R. 1996. Interaction between ingested feed and the digestive system In poultry. Journal of Applied Poultry Research, 5:8695.

Dhama, K., Tiwari, R., Chakraborty, S., Saminathan, M., Kumar, A., Karthik, K., Wani, M.Y., Amarpal, Singh, S.V. and Rahal, A. 2014. Evidence based antibacterial potentials of medicinal plants and herbs countering bacterial pathogens especially in the era of emerging drug resistance: An integrated update.
International Journal of Pharmacology 10: 1-43.

EL-Faham, A.I., Nematallah, G.M., Ali, and Hayam M.A.A. El-Maaty. 2014. Effect of using some natural feed additives to substitute antibiotic growth promoters on performance and blood parameters of broilers. Egyptian Poultry Science Journal, 34 (III): 735-750.

Fallah, R., Kiani, A. and Azarfar, A. 2013. A review of the role of five kinds of alternatives to in-feed antibiotics in broiler production. Journal of Veterinary Medicine and Animal Health, 5: 317-321

Fasuyi, A.O. and Oloyede, T.A. 2017. Garlic (Allium sativum) powder as an additive in broilers (1-28 Days). Phase 1: Growth performance and hypocholesterolemic effects. Journal of Experimental Agriculture International, 17(6): 1-12

Gade, D.S., Dhumal, M.V., Nikam, M.G. and bhosale, D. 2017. Influence of different levels of xylanase enzyme on performance, litter quality and economics of broiler chicken International Journal of Agricultural Science and Research, 7: (3) 73-82.

Grashorn, M.A. 2010. Use of phytobiotics in broiler nutrition - an alternative to infeed antibiotics. Journal of Animal and Feed Sciences, 19: 338-347.

Javed, M., Durrani, F.R., Hafeez, A., Khan, R.U. and Ahmad, I. 2009. Effect of aqueous extract of plant mixture on carcass quality of broiler chicks. Journal of Agricultural and Biological Science, 4: 37- 40.

Karangiya, V.K., Savsani, H.H., Patil, S.S., Garg, D.D., Murthy, K.S., Ribadiya, N.K. and Vekariya, S.J. 2016. Effect of dietary supplementation of garlic, ginger and their combination on feed intake, growth performance and economics in commercial broilers. Veterinary World, 9(3): 245-250.

Kocher, A., Choct, M., Porter, M.D. and Broz, J. 2002. Effects of feed enzymes on nutritive value of soybean meal fed to broilers. British Poultry Science, 43: 54-63.

Mahmood, S., Furqan Saleem, M., Ahmad, F., Abbas, G., Mahmood, A., Qamar, S.H. and Zia-ur-Rehman, M. 2014. Comparative effect of different commercial herbal 
growth promotors on performance, minor body parts weight and immune response in broilers. Advances in Zoology and Botany, 2(4): 69-74.

Malathi, V. and Devegowda, G. 2001. In vitro evaluation of non-starch polysaccharide digestibility of feed ingredients by enzymes. Poultry Science, 80: 305-309.

Marron, L., Bedford, M.R. and Mccracken, K.J. 2001. The effects of adding xylanase, vitamin $\mathrm{C}$ and copper sulphate to wheatbased diets on broiler performance. British Poultry Science, 42: 493-500

Mathlouthi, N., Bouzaienne, T., Oueslati, T., Recoquillay, F., Hamdi, M. and Urdaci, M. 2012. Use of rosemary, oregano, and commercial blend of essential oils in broiler chickens: In vitro antimicrobial activities and effects on growth performance. Journal of Animal Science, 90: 813-23.Mehala, C. and Moorthy, M. 2008. Production performance of broilers fed with Aloe vera and Curcuma longa (turmeric). International Journal of Poultry Science, 7: 852-856.

Moustafa, K.E.K. 2006. Effect of using commercial and natural growth promoters on the performance of commercial laying hens. Egyptian Journal of Poultry Science, 26: 941-965.

Oleforuh-Okoleh, V.U., Chukwu, G.C. and Adeolu, A.I. 2014. Effect of ground ginger and garlic on the growth performance, carcass quality and economics of production of broiler chickens. Global Journal of Bioscience and Biotechnology, 3(3): 225-229.

Onu, P.N., Madubuike, F.N., Onu, D.O. and Ekenyem, B.U. 2011. Performance and economic analysis of broiler starter chicks fed enzyme supplemented sheep manurebased diets. Journal of Agricultural
Biological Science, 6: 14-19.

Platel, K. and Srinivasan, K. 2004. Digestive stimulant action of spices: a myth or reality. Indian Journal of Medical Research, 119: 167-179.

Puvaca, N., Simin, M.T., Kostadinovic, L., Lukac, D., Ljubojevic, D., Popovic, S. and Tasic, T. 2016. Economic efficiency coasts of broiler chicken production fed dietary garlic, black pepper and hot red pepper supplements. http://www.custose agronegocioonline.com.Gadhw

Saini, J., Sharma, T., Mitharwal, N., Gadhwal, R.S., Jakhar, A., Kumar, S. and Baindha, A. 2015. Effect of feeding Ashwagandha and enzyme alone and in combination on the carcass traits of broiler chicks. International Journal of Scientific Research. ISSN No. 2277-8179.

Torres, C., M.A. Moreno and Zarazaga. 2010. Prudent use of antimicrobial agents: Not just for humans. Enfermadades Infecciosus Microbiologia Clinica, 28: 669-671.

Singh, V.B., Singh, V.K., Tiwari, D., Gautam, S., Ruma Devi, Singh, S.P., Chaturvedi, S. and Singh, P. 2018. Effect of a Phytogenic Feed Additive Supplemented Diet on Economic Efficiency and Cost of Production of Broiler Chickens. International Journal of Current Microbiology and Applied Sciences ISSN: 2319-7706 Special Issue-7 pp. 28312837.

Windisch, W., Schedle, K., Plitzner, C. and Kroismayr, A. 2008. Use of phytogenic products as feed additives for swine and poultry. Journal of Animal Science, 86: 140- 146.

Yang, Y., Iji, P.A. and Choct, M. 2009. Dietary modulation of gut microflora in broiler chickens: A review of the role of six kinds of alternatives to in-feed antibiotics. World Poultry Science Journal, 65: 97-114.

\section{How to cite this article:}

Singh, P., V.K. Singh, D. Tiwari, S. Gautam, V.B. Singh and Vipin. 2020. Effect of Phytobiotic and Exogenous Enzyme Supplementation on Economic Efficiency and Cost of Production of Broiler Chickens. Int.J.Curr.Microbiol.App.Sci. 9(05): 1852-1860.

doi: https://doi.org/10.20546/ijcmas.2020.905.210 